Collection: EFI 2008 Annual Conference Week - Orvieto (Italy) Adaptation of Forest Landscape to Environmental Changes Guest Editor: Giuseppe Scarascia Mugnozza (CRA - Rome, Italy)

\section{Payments for forest environmental services: organisational models and related experiences in Italy}

\author{
Gatto P, Pettenella D, Secco L
}

In the last decades, with the rapid structural changes in society and in consumers' attitudes at both global and local scale, forest landowners and managers are facing a complex and multi-faceted demand, in which the role of forest services - recreation, landscape, biodiversity, C-sequestration amongst others - has become increasingly important. New forest policy tools are therefore required to create or consolidate the shift in forest management from the traditional production function towards more multi-stakeholders and multifunctional goals. On the basis of the existing theoretical background and by means of three explanatory-exploratory case-studies chosen amongst the few experiences present in Italy, the paper seeks to analyse the potentials and challenges in different organisational PES models applied to the provision of forest services in the country, with a special focus on tourism-related environmental services. The analysis shows that the markets for the various forest services have different drivers, sizes and levels of maturity. Performances in effectiveness, efficiency and equity are also highly variable. Strengths, weaknesses, opportunities and threats for new private and mixed private-public initiatives need therefore to be further explored before assessing the true potential for implementing PES in Italy.

Keywords: Payments for environmental services, Market-based instruments, Forests, Italy

\section{Introduction}

At the dawn of third millennium, the Italian forestry sector indubitably calls for innovation, both in management and organisational models, as is happening in other European countries (Rametsteiner et al. 2006). Many and diverse driving forces propel the scenario changes. With the strong competition on the global markets for timber products, and the globalisation of forest issues and the related policy context where decisions are taken, forest entrepreneurs are constantly re-

Dept. of Land and Agro-forestry Systems, University of Padua - Agripolis, v.le dell'Università 16, I-35020 Legnaro (PD Italy)

\section{@ Paola Gatto (paola.gatto@unipd.it)}

Received: Apr 08, 2009 - Accepted: Apr 15, 2009

Citation: Gatto P, Pettenella D, Secco L, 2009. Payments for forest environmental services: organisational models and related experiences in Italy. iForest 2: 133-139

[online: 2009-07-30] URL:

http://www.sisef.it/iforest/ ducing their market power in influencing prices and factors allocation. Locally, southern European forest owners are affected by long-standing structural problems - highly fragmented forest estates, exposure to natural hazards (fires, difficulties with natural regeneration), low market access - all factors resulting in low levels of profitability for wood production (Palahí et al. 2008). On the other hand, the demand for Non Wood Forest Products and environmental services has grown rapidly in the last decades, highlighting the need for a more multifunctionally-oriented forestry but also fuelling conflicts amongst the different objectives and stakeholders (Solberg \& Miina 1997, Hellström 2001, Niemelä et al. 2005, Janse \& Ottitsch 2005). Finally, timber and forests are nowadays perceived not only as important natural resources, but also as part of the historical and cultural heritage of one country (Parrotta et al. 2006) and this in turn broadens the number and the type of stakeholders involved in the decision-making processes (Buttoud 1999, Appelstrand 2002, Buttoud et al. 2004).

In this complex scenario, new forest policy instruments are needed that can remunerate in an efficient way those forest owners and managers providing forest collective values and conserving forest multifunctionality. Moving away from the traditional "command and control" approach, these instruments should be soft and participative, characterised by an innovative multi-relationship environment and inspired by a bottomup approach. In other words, they should embody the most-advocated shift from "government" to "governance" in the management of forest resources (Buttoud 2006, Shannon 2006).

In recent years, research on environmental and forest policies has rapidly progressed, and a full set of new and different tools has been proposed in order to achieve multifunctional forestry objectives in a sustainable manner (Merlo \& Briales 2000, Cubbage et al. 2007). Among these tools, the so-called Payments for Environmental Services (PES) have received a great deal of attention, and many applications and case-studies are now available, especially in developing countries (see, e.g., the well-documented reviews by Perrot-Maître \& Davis 2001, Pagiola et al. 2002, Landell Mills \& Porras 2002, Wunder et al. 2008). The rationale behind PES is the commoditisation of public goods by means of market creation, in which beneficiaries/consumers directly pay the producers for the product or service provided. The idea looks quite simple and appealing in its theoretical formulation, but several key-issues need to be resolved before PES can be considered effective and efficient tools for sustainable forest management.

Within this context, this paper seeks to understand what are the key-factors making PES a successful income-generation opportunity for forest entrepreneurs/landowners. The study focuses on Italy, a country where these schemes have so far been scarcely applied and timber production is often no longer the main source of income for forest managers. The lessons learned from the Italian experience can also help to ascertain whether PES, as a means to pay for forest multifunctionality, can ultimately contribute towards the conservation of forest landscapes in a Southern European context.

\section{PES: basic concepts}

In the international literature, the most-acknowledged definition of a PES scheme is probably that of Wunder (2005), also reported in Engel et al. (2008), whose pillars are the identification of a well-defined environmental service, the voluntariness of the transaction, the existence of both buyers and sellers (at least one each) and the continuity of the provision in time.

One crucial point in the definition is what 
Tab. 1 - A classification of some PES schemes in Italy focused on the role of public authorities in diverse organisational models.

\begin{tabular}{|c|c|c|c|c|}
\hline \multicolumn{2}{|c|}{$\begin{array}{l}\text { Role of the } \\
\text { public sector }\end{array}$} & PES mechanisms & Application to the forest sector & Examples in Italy \\
\hline $\begin{array}{l}\text { Direct } \\
\text { role }\end{array}$ & 1. Direct control & $\begin{array}{l}\text { Purchase of emission licences } \\
\text { and permits, sometime with } \\
\text { public funds }\end{array}$ & $\begin{array}{l}\text { C-offsets (CDM and JI projects under } \\
\text { Kyoto Protocol rules) or Biodiversity- } \\
\text { offsets projects (Nature } 2000 \text { Pay- } \\
\text { ments) }\end{array}$ & $\begin{array}{l}\text { Practical experiences not yet } \\
\text { available in Italy }\end{array}$ \\
\hline \multirow[t]{2}{*}{$\begin{array}{l}\text { Indirect } \\
\text { role }\end{array}$} & 2. Indirect control & $\begin{array}{l}\text { Best Management Practice con- } \\
\text { tracts, sometimes with public } \\
\text { funds }\end{array}$ & $\begin{array}{l}\text { Tariffs on drinking-water provision } \\
\text { services as a compensation for best } \\
\text { forest practices implemented in the wa- } \\
\text { ter catchment area }\end{array}$ & $\begin{array}{l}\text { Water tariffs in Piedmont and } \\
\text { Emilia Romagna Regions }\end{array}$ \\
\hline & $\begin{array}{l}\text { 3. Allocation of } \\
\text { property rights }\end{array}$ & $\begin{array}{l}\text { Selling and purchasing of licences } \\
\text { and collection permits for con- } \\
\text { trolling volumes of resources }\end{array}$ & $\begin{array}{l}\text { Mushrooms, truffles and other NWFPs } \\
\text { harvesting permits, hunting licences }\end{array}$ & $\begin{array}{l}\text { Wild-mushroom picking permits } \\
\text { in several mountain areas }\end{array}$ \\
\hline \multirow[t]{2}{*}{$\begin{array}{l}\text { No } \\
\text { significant } \\
\text { role }\end{array}$} & $\begin{array}{l}\text { 4. Contextual } \\
\text { control }\end{array}$ & $\begin{array}{l}\text { Direct trade of PES between pro- } \\
\text { viders (usually private business- } \\
\text { men) and buyers of the environ- } \\
\text { mental services }\end{array}$ & $\begin{array}{l}\text { Tourist-recreational, soft-adventure, } \\
\text { cultural, educational activities, C-Off- } \\
\text { sets in the voluntary market }\end{array}$ & $\begin{array}{l}\text { Adventure Parks; environmental } \\
\text { education services; peri-urban } \\
\text { forests or plantations selling C- } \\
\text { credits on the voluntary market }\end{array}$ \\
\hline & & $\begin{array}{l}\text { Corporate Social Responsibility- } \\
\text { related initiatives, such as selling } \\
\text { of eco-labelled or certified } \\
\text { products and services }\end{array}$ & $\begin{array}{l}\text { Certification of forest management } \\
\text { based on Sustainable Forest Manage- } \\
\text { ment (SFM) standards }\end{array}$ & $\begin{array}{l}\text { Several private, public and com- } \\
\text { munity-forests certified according } \\
\text { to SFM standards; NWFPs labels } \\
\text { of origin }\end{array}$ \\
\hline
\end{tabular}

is considered as an environmental service. Most authors (see for example Landell Mills $\&$ Porras 2002) include in the list: C-sequestration, biodiversity conservation, watershed protection and influence on water regimes, landscape beauty, and bundled services. The reference to the ecosystem instead of to the environment, adopted for example by the Katoomba Group (2008), may restrict the field of application of PES schemes even more.

According to both these definitions, recreation can be strictly considered neither an ecosystem nor an environmental service. This perhaps partially explains why only a few case-studies of PES in Europe and no case-studies in Italy have been reported in the very recent review by Wunder et al. (2008), despite several examples of "environmental-recreational" services being available (Merlo et al. 2000, Mantau et al. 2001). Recreation is indeed one of the most important products of a multifunctional silviculture, where it is jointly produced - and therefore intimately bundled - with other public goods and services (Merlo \& Croitoru 2005, Cesaro et al. 2008). Omitting it from the family of environmental services would cut out several possibilities for implementing PES in forestry, at least in an Italian context, and this is the pragmatic reason why, in this paper, the broader definition for PES proposed by Mantau et al. (2001) is adopted.

The basic structure of a PES scheme encompasses the activation of a mechanism ensuring the flow of payments from beneficiaries to providers (Pagiola 2002). This needs to be backed by a clear identification of the service traded, also in term of the economic value of the benefit marketed, which is crucial but sometimes difficult to be estimated. The suppliers and the buyers of the service need also to be clearly defined, in terms of both responsibilities and rights. In fact, the implementation of PES schemes often requires a context of full allocation or assignment of property rights, where rights holders are entitled to claim the price for the environmental good produced. Markets for environmental services are also "artificially" created by regulatory acts of public agencies, having mainly a "cap and trade" nature, like for example the C-credits market under the Kyoto Protocol.

\section{Conceptual and methodological framework}

A good deal of the PES literature concentrates on different PES taxonomy. A comprehensive classification framework - called the PES Matrix- has recently been produced by the Katoomba Group (2008). This framework arranges PES schemes into three main categories, mainly based on the type of payment mechanism: Compliant, Governmentmediated and Voluntary. In addition, other criteria based on market features like size, participants, shapers and service providers are used to classify the PES schemes. Nevertheless, it stands to reason that one of the key-aspects for differentiating PES schemes is the level of involvement of public authorities with respect to the private actors in PES markets creation.

In this paper, the institutional arrangements and organisational models linked to different roles of Governments in markets - according to different economic theories (Rametsteiner
2000) and to the abovementioned PES Matrix - are considered to have a very pivotal role in the design of successful PES schemes. Therefore, a classification focused mainly on the role of the public institutions in creating, supporting or controlling the markets for PES has been developed (Tab. 1). According to this classification, three main organisational models (with two additional sub-models) suitable for describing the institutional frameworks for PES implementation in Italy have been identified. These models can be systematised as: i) the Government has a direct role ("Direct control"); ii) the Government has an indirect role ("Indirect control" and "Allocation of property rights"); iii) the Government has no significant role ("Contextual control"). Hereafter, the organisational models fitting into the Italian context are briefly described:

1. Direct role - Direct Control: market creation occurs under direct control by public institutions of the rules and the correct functioning of the market mechanism, e.g., through Cap-and-Trade programmes, where public institutions identify market agents and emission caps. According to the Katoomba Group's classification, these are compliant schemes, in which the entrance by agents is mandatory. Examples include the C-offsets initiatives implemented under the Kyoto Protocol rules (activities under the European Trading Systems and the Clean Development Mechanism - CDM and Joint Implementation - JI - projects) or the Biodiversity-offsets initiatives like those under the Habitat and Birds Directives of the EU (European Union 2003). Payments can occur through direct pay- 
ments between public authorities and the services' providers or through intermediary-based transactions, and sometime are connected to the use of public incentives.

2. Indirect role - Indirect Control: public institutions play a general role in defining the principles regulating the market (i.e., services, actors, rules and payment mechanisms); in such a way, they perform an indirect control on the market and the various players, acting mainly as mediators. The Italian administrative system being strongly based on decentralisation, major responsibilities in decision-making and policy implementation in the forestry and several other sectors, such as water supply, are given to the Regional authorities (Andrian et al. 2002). This means that once the general rules have been established at State level, the details for their implementation are left to the local authorities (i.e., $21 \mathrm{Re}$ gions and Autonomous Provinces). This situation results in different local institutional and legal frameworks for PES schemes implementation. One example in Italy is the possibility of endorsing PES-type schemes for tap water provision services, regulated through the National Act on the Integrated Water Cycle (LN 36/1994 Muraro 2008). This assigns the power to the Regional authorities to implement rules at local level through which public/private water services providers can charge additional water tariffs from final users to be transferred back to forest owner or managers. The role of Government here is to ensure the enforcement of the contract between the parties and to monitor property rights (Rametsteiner 2000). Direct payments (commoditised through best management practices contracts) or intermediary-based transactions are included as payment mechanisms. Public funds may be used.

3. Indirect role - Allocation of property rights: the Government acts mainly through the assignment of property rights to landowners, so that "public" or "common" goods are transformed into private goods and commercialised. The PES scheme is voluntarily implemented by the environmental service's providers, while the buyers only enter the market if they are interested in the good offered. As in the previous one, the role of public authorities might be "to develop regulations and environmental certificates for controlling volumes of resources" (Rametsteiner 2000). This is the case, for example, for recreational activities linked to hunting or nonwood forest products (NWFPs) harvesting (e.g., wild mushroom picking), conditional upon the purchase of licences and permits, whose profits should go to the land-right holders. Besides allocating property rights, the Government sometime acts in a similar fashion to the "cap-and-trade" programmes, for example setting ceilings or quotas for permits (mainly on the basis of assuring a sustainable use of the resource). Payment mechanisms include only private transactions.

4. No significant role - Contextual control (Willke 1996, quoted in Rametsteiner 2000): the Government prefers soft interventions (or no interventions) that should direct and support economic activities rather than regulate them. Thus, it uses only weak informational tools, playing an educational and promotional role, based on distributing information to market agents and stakeholders. The implementation of the initiatives is entirely voluntary. The transactions are private and occur through either direct trade (over the counter payments, sale of access tickets), as in the case of tourist recreational activities, or through the sale of eco-labelled or certified products and services.

Although the compliance criterion is not the main classification key, the models are consistent with the Katoomba group's payment types (2008). In fact, they partially match the classification proposed by the PES Matrix, where the "Direct control" of Government in establishing PES schemes corresponds to the "Compliant" mechanisms, the "Indirect control" corresponds to the "Government-mediated" and finally the "No significant role" category refers to the "Voluntary" mechanisms. The described organisational models show a decreasing degree of compliance going from the "Direct control" model down to the 'No significant role' one.

To conclude, the proposed framework highlights that public institutions can have different roles in PES schemes implementation, progressing from simply an informational function to a more complex and greater responsibility in setting up the market, up to the direct control of market agents and transactions. In any case, Governments are never absent from the PES scenario.

Based on the conceptual framework developed in Tab. 1, three paradigmatic casestudies on different organisational models have been identified and selected in the Italian context.

The first case-study - based on an indirect control model - concerns the drinking water supply service in two Italian regions: Piedmont and Emilia Romagna (the only two Regions where this PES tool has been put in place so far). The second case-study - emblematic of an allocation of property rights model - deals with the recreational activities associated with wild mushroom gathering, specially focused on a rural market located in the Apennines. The third and last casestudy, classified in the category no significant role, considers the provision of recreational services in tree-canopy walks (usu- ally called "Adventure Parks" in Italy) that have appeared recently in several mountain areas.

No case-studies have been selected for the remaining two types of organisational models. As regards the model where Government has direct role, no initiatives have so far been implemented in Italy, as the European Trading System does not allow the exchange of $\mathrm{C}$-sink related projects while CDM and JI projects are not allowed to be implemented in Italy. As regards the model where Government has a weak informational role in certification and labelling initiatives, no case-studies have been selected. The Italian experiences regarding the involvement of public authorities in forest management certification initiatives are quite unusual (Secco \& Pettenella 2006) and therefore cannot be considered paradigmatic examples to analyse for the purpose of this paper.

According to Yin (1993), our case studies can be labelled as exploratory-explanatory case studies. The first one - "Water tariffs" has been investigated mainly by means of internal documents and a review of current legislation. The other two - "Wild-mushroom permits" and "Adventure Parks" - have been investigated by collecting data through an internal document review and semi-structured interviews of local stakeholders, including private landowners and entrepreneurs, visitors and local public authorities. The investigatory approaches are based on a methodology formalised by Marshall et al. (2006).

\section{Profiles of the case studies}

\section{Water tariffs}

According to the general provisions of the National Act 36/1994, the mechanism enforced in the Piedmont Region (Regional Law - RL 17/1997, RL 16/1999 and Decree $38-8849 / 2008$ ) implies that a 3 to $8 \%$ share of the income from the water tariff (collected by the Public Water Authorities) is transferred back to the Mountain Communities, i.e., to consortia of Municipalities in the mountain areas. These, in turn, have to invest the funds in projects aimed at "maintenance and conservation of the mountain areas". In 2007, 18.5 thousand Euros were collected, meeting $54 \%$ of the total budget spent for "hydro-geological and watershed management" - this however may mean hydraulic works on the river banks or beds and not necessarily on forest maintenance.

Fewer details are available for the Emilia Romagna Region, due to the more recent implementation of the scheme (defined with RL 25/1999). The mechanism is similar to that operating in Piedmont, however here the share of the water tariff to be used for forest management is $6 \%$. The rules in this case specify that at least $50 \%$ of what should go to mountain areas is used strictly for forest 
maintenance.

Regulation of water regimes, reduction of soil erosion and other hydro-geological risks are the main goal of this scheme. The rationale is to pay forest owners and managers for maintaining stable upland forests; the beneficiaries are the lowland communities who enjoy improved protection against floods.

The remarkably different share of the water tariff earmarked for similar forest services in the two Regions indicates that the amount of payment is established mainly on politica grounds rather than being based on the evaluation of the non-market benefits connected with the management of water catchment basin.

\section{Wild mushroom permits}

Wild-mushroom picking is regulated by law, mainly with the purpose of ensuring that mushroom harvesting activities are sustainable and do not have a too strong negative impact on other components of the forest ecosystem. National Act 352/93 establishes the general framework, on the basis of which the Regional Governments set up detailed regulations for their territory. Forest landowners are free to collect as many mushrooms as they want or need from their land with no restrictions, while all the other pickers are subjected to the purchase of daily, weekly or monthly permits and to daily caps (usually $2 \mathrm{~kg}$ of mushrooms per day per person). The permits are sold by the Local Authorities, Mountain Communities or by the single Municipalities. Permits are usually cheaper, or even free, for local residents, and more expensive for visitors.

The specific explanatory example for this organisational model comes from the area of Borgotaro in the Apennines (Pettenella et al. 2008). Here, the price for a daily picking permit ranges between 6 Euros (for residents) and 15 Euros (for non residents), while a six-months permit costs between 67 Euros and 150 Euros. About 36 thousands permits were sold in 2005; assuming an average of 10 Euros per permit, the yearly revenue totals 360 thousand Euros. In Borgotaro this money is used by the local forest owners' associations for forest conservation and management including forest practices aimed at increasing mushroom yields, making it an effective mechanism for forest maintenance.

The re-use of the permit income in forest maintenance may be explicitly set by the legislative framework, but this is not always the case. Given the very de-centralised level at which the permit money is raised and spent, it is generally very difficult to obtain a clear picture of the actual use of the funds in forest maintenance.

\section{Adventure Parks}

In Italy, Adventure Parks are a relatively new product in the panorama of the structured tourist and recreational facilities linked to forests and mature trees. They have been created in the last five years, following the development path of similar structures existing in France since the beginning of the 1990's. An Adventure Park is a series of acrobatic trails built on high tree trunks, with ropes and wires attached to different trees. In their conception, Adventure Parks are similar to the American Challenge Courses or to the Canopy Walks existing in some tropical forests, but their aims include educational, developmental, and recreational goals.

According to a recent study (Loreggian 2008), there are now about 70 similar structures in Italy, mostly located in mountain areas with high tourism vocation. It is diffi- cult to estimate the overall market in terms of visitors number, since they vary widely according to the location. Visitors to an Adventure Park usually buy a ticket to gain access to the park and a ticket costs 10 Euros on average. Assuming around 8 thousand visitors per year, with an initial investment of 250 thousand Euros and annual management costs of 30 thousand Euros, the breakeven point of the investment is reached after the fifth year of operation.

The link with the PES mechanism lies in the provision of a recreational service strictly connected with the presence of the trees, and the net revenues from the Park should serve the maintenance of the forest in which the activity is based.

In Tab. 2, besides the type of service produced and the payment mechanism, three other important features of the case-studies are analysed and compared, namely the market drivers, market size and level of market maturity.

The market drivers responsible for the development of the three PES schemes are rather evident: provision of basic services accompanied by an increased awareness of the urban population towards water quality for the water tariff case-study, demand for forest recreation for the other two, along with interest in traditional local food in the case of the wild-mushroom permits. What is rather different among the three case-studies is the market size. For the water tariffs, the market is large, being all the households and businesses in the two regions (and potentially in all the country). The size of the market for mushroom permits is of medium importance at local level, while Adventure Parks are related to scattered niche markets. For the last two there is a potential for increasing the market size. As regards the wild

Tab. 2 - Profiles of the case-studies under analysis. Sources: Regione Piemonte 2008 (unpublished data), Pettenella et al. 2008, Loreggian 2008.

Profiles

Type of Environmental Service Regulation of water regimes produced by the forest and traded (quality, quantity and regularity through PES scheme

Payment mechanism of flows) Payments (tariffs) from beneficiaries (water end-users) are used by service suppliers (forest landowners or managers) for forest management aimed to service provision

Market drivers Provision of basic services like water; increased awareness of urban population towards water quality

\begin{tabular}{llll}
\hline Market size & Large & Medium & Niche \\
\hline Level of market maturity & Young: pioneer experiences & $\begin{array}{l}\text { Mature: long tradition in Italy, } \\
\text { consolidated experiences }\end{array}$ & $\begin{array}{l}\text { Young: total innovation, under de- } \\
\text { velopment }\end{array}$ \\
\hline
\end{tabular}

Recreation through the picking activity

Payments received by service suppliers (forest landowners or managers) through sale of permits and paid by end-users (mushroom pickers) are used for forest conservation/ maintenance Increasing demand for forest recreational activities and for local traditional foods and specialities
Recreation through an open-air sporting activity

Service's suppliers (forest owners or managers) are directly paid by the end-users for forest management specifically oriented to provide the service

Opportunity for business based on an increasing demand for recreation in forests

\section{Adventure Parks}


mushroom permits, at aggregate (national) level the role is already not so marginal: the Italian Statistical Office estimates 3300 tons of wild mushrooms harvested in 2005; assuming that $80 \%$ is collected by permit-paying pickers, with an average price of $10 €$ permit $^{-1}$ and quantity of $2 \mathrm{~kg}$ picker $^{-1}$ day $^{-1}$, the total value of the permit sales is $13.2 \mathrm{M} €$ $\mathrm{yr}^{-1}$.

Finally, the level of maturity also differs widely amongst the three: the experiences of implementing PES schemes linked to water tariffs are so far at a very pioneering and immature stage. Mushroom picking has a long tradition in Italy, with consolidated experiences, based on a well-structured and mature market. Adventure Parks are a totally new business activity, characterised by high requirements for innovation and technical capacities.

\section{Results and discussion}

Following Pagiola et al. 2002 the performance of the three case-studies under analysis can be assessed thorough different criteria, in particular (Tab. 3):

- the effectiveness of the scheme in achieving the desired levels of provision of the service, and in turn its capacity to contribute towards the conservation of forest resources;

- the effectiveness of the scheme to generate revenues for the providers, also in terms of regularity over time. This is considered one of the most attractive features of PES schemes, especially if compared with the long lapse of time for forest revenues to materialise or with the uncertainty of public subsidies to silviculture. By creating new chances for landowners to keep them in forestry and avoid abandonment, this aspect can also ultimately contribute to the scope of resource conservation;

- the efficiency, that is to say the capacity of the scheme to achieve the desired level of results with the minimum level of expenditures. This can be measured in terms of opportunity cost of the foregone land use (Pagiola 2002), in a wide economic framework that also considers the role and extent of transaction costs, both public and private;

- the equity, referring to the capacity of the scheme to involve all those who are eligible and entitled to take part in it. This is a crucial aspect in the light of the innovative participatory approaches underpinning modern rural development.

In general, the effectiveness of the PES scheme in the provision of strict environmental services - like regulation of water regimes - is site-specific and difficult to ascertain and measure. The forest area under the scheme could be used as a first proxy for the extent of service provision. However, we are mainly dealing with already existing forests,

Tab. 3 - The three case-studies in the light of the performance criteria adopted.

\begin{tabular}{llll}
\hline \multicolumn{1}{c}{ Case Study } & \multicolumn{1}{c}{ Water tariffs } & \multicolumn{1}{c}{$\begin{array}{c}\text { Wild-mushroom } \\
\text { permits }\end{array}$} & Adventure Parks \\
\hline $\begin{array}{l}\text { Effectiveness in } \\
\text { service provision }\end{array}$ & $\begin{array}{l}\text { Variable } \\
\text { (depend on many } \\
\text { factors) }\end{array}$ & High & High \\
\hline $\begin{array}{l}\text { Effectiveness in } \\
\text { income generation }\end{array}$ & Low & $\begin{array}{l}\text { Variable } \\
\text { (from high to low) }\end{array}$ & High \\
\hline Efficiency & $\begin{array}{l}\text { Low } \\
\text { (high transaction costs) }\end{array}$ & $\begin{array}{l}\text { Low } \\
\text { (high transaction costs) }\end{array}$ & High \\
\hline $\begin{array}{l}\text { Equity in benefits } \\
\text { distribution }\end{array}$ & Low & $\begin{array}{l}\text { Variable } \\
\text { (potentially very high) }\end{array}$ & Generally low \\
\hline
\end{tabular}

where the additional effects of the schemes on improving forest conservation are hard to single out since they depend on forest management practices (what the PES scheme pays for), but also on other forest characteristics like forest cover and soil type and on environmental factors like climate, especially rainfall. In the case of recreational services like mushroom picking activities and Adventure Parks, the effectiveness in terms of level of service provided is more easily identifiable and generally higher than with water services. However, whenever the recreational activities implemented by the PES scheme cross the forest sustainability threshold, the provision of environmental services - sensu stricto - can be seriously threatened.

Effectiveness in income generation is also diverse within the organisational models under examination. For water tariffs, the scheme in place in the Piedmont Region has so far generated funds to meet only $50 \%$ of the total needs, showing a low effectiveness. For the wild mushrooms permits, the effectiveness depends both on the capability of local landowners to enforce the mushroom property rights regime so as to raise money through the sale of permits and the general ability of the scheme to generate local wealth through networking and marketing initiatives, of which Borgotaro is a good example. Finally, Adventure Parks have shown good results in income generation, given the relatively short payback periods.

Measuring the efficiency of the scheme means evaluating whether it is worthwhile running it, in other words assessing whether the benefits it produces are higher than the costs to achieve those benefits. In PES schemes, this balance can be strongly affected by transaction costs, which could be approximated by the number of actors involved in the schemes on both sides: public (institutions) and private (e.g., number of landowners). Organisational models implying a relatively large number of intermediate steps between providers and beneficiaries, or a large number of small estates - like for example the water tariffs and wild mushroom schemes have high transaction costs and therefore low efficiency. On the contrary, where fewer actors are involved, like in the case of Adventure Parks, and agreements are directly negotiated between the landowner and the concessionary, transaction costs can be significantly reduced and a higher level of efficiency can be achieved.

Finally, the equity criteria is met when the scheme has the capability to achieve, directly or indirectly, a fair distribution of benefits to the members of the local community, resulting in turn in an higher social acceptability and thus reducing the risks of conflicts for the use of natural resources. Different issues can be at the basis of lack of equity; the gaps in the scientific understanding of the causeeffects relationships can be one important source of unfairness, as is happening for water tariffs in Italy. The case-studies have shown that the decision on the amount of payment due and on who are the final recipients has been so far only a mere political matter, with no consideration on the true value of the service provided. This might lead to unfair discriminations, based on local interests and lobbies.

For the other two case-studies, providing essentially a recreational service to tourists, the equity of the scheme is related to their ability to trigger other income-generating activities through territorial market initiatives. The organisational model put in place in Borgotaro is a very good example of this, being based on a network involving "not only forest-based small and medium-size enterprises but also other institutional, economic and social actors", proving to be "not only economically viable and less risky, but also equitable in distribution of benefits, and effective in stimulating the local economy as a whole" (Pettenella et al. 2008). For their essentially private nature and the infancy of the business, Adventure Parks are at the moment less capable of generating multiplier effects, however they may do so in the future when turning in a well-known attraction of an area. 


\section{Conclusions}

The analysis on the features and performance criteria of the three case-studies shows that the Italian experience in the application of PES schemes is still at its debut and this is at the root of the wide variability of some crucial factors for PES development, namely:

1. the size of markets, which varies largely from niche-medium for recreational services to large for water services;

2. the level of maturity of markets, which is rather different depending on the service: while schemes for water services can be considered pilot experiences, those for recreational services show a relatively higher market maturity and better market stability, implying lower entrepreneurial risks; however, allocation of property rights sometimes appears to be problematic in this case;

3. finally, the involvement of local communities, which is also significantly varying, and when it occurs, requires shared objectives and commitment to capacity building. The innovative participatory approaches underpinning modern decisionmaking processes related to natural resources uses and environmental/social conflicts management might positively contributing in this key-aspect of PES schemes implementation.

Some other preliminary conclusions can be drawn from the analysis. Looking at the three organisational models embodied by the case-studies - e.g., the "Indirect control" (water tariff), "Allocation of property rights" (wild-mushroom permits) and "Contextual control" (Adventure Parks) - it appears that higher effectiveness and efficiency performances can be associated to those organisational models where the role of public institutions is softer.

Still, there are at least two good reasons why this finding must be treated with caution. First, it is clearly affected by either the immaturity of the schemes (e.g., in the case of water tariffs) or the imperfectness of the implementation tools design (i.e., wild mushroom permits regulation was conceived with different purposes to those related to a PES scheme implementation). Secondly, even if the involvement of public institutions might increase transaction costs, such involvement might be important in order to guarantee or to improve both the environmental sustainability of the initiatives and the fairness in the schemes' benefits distribution.

To conclude, it is rather early to draw a final balance of the scattered Italian experience in the application of PES schemes. This overview is intended to contribute towards the provision of a first methodological framework for further analysis and research in this field, highlighting some of the crucial issues in PES design and application. The preliminary findings of this case studies' analysis almost substantiate the international literature contents and point out that the design of successful PES schemes is based on a well-balanced mix of essential requirements. These requirements include, amongst others: clear understanding of the cause-effect relationships at different scales, proper stakeholders' involvement, positive entrepreneurial attitude and networking capacity, capacity building, minimisation of transaction costs, clear governance mechanisms and transparent decision-making processes with soft Governments interventions, communication and green and territorial marketing initiatives. Only well-designed PES schemes have a good potential for generating revenues in the forest sector and, ultimately in the conservation of forest ecosystems and landscapes.

\section{References}

Andrian G, Musumeci L, Pettenella D, Secco L (2002). Cross-sectoral linkages in mountain development. Italy Case Study. FAO Forestry Department - Policy and Institutions Branch, Rome, pp. 68.

Appelstrand M (2002). Participation and societal values: the challenge for lawmakers and policy practitioners. Forest Policy and Economics 4: 281-290. - doi: 10.1016/S1389-9341(02)00070-9 Buttoud G (1999). Principles of participatory processes in public decision-making. In: "Regional forest programmes: a participatory approach to support forest based regional development" (Niskanen A, Väyrinen J eds). EFI Proceedings No. 32, European Forest Institute, Joensuu, Finland.

Buttoud G (2006). Participation in forest policy processes: apple-pie, or new mode of governance? Schweizerische Zeitschrift für Forstwesen 157: 10-429.

Buttoud G, Solberg B, Tikkanen I, Pajari B (2004). The evaluation of forest policies and programmes. EFI Proceedings No. 52, European Forest Institute, Joensuu, Finland.

Cesaro L, Gatto P, Pettenella D (2008). The multifunctional role of forests - policies, methods and case studies. EFI Proceedings No. 55, European Forest Institute, Joensuu, Finland.

Cubbage F, Harou P, Sills E (2007). Policy instruments to enhance multi-functional forest management. Forest Policy and Economics 9: 833851. - doi: 10.1016/j.forpol.2006.03.010

Engel S, Pagiola S, Wunder S (2008). Designing payments for environmental services in theory and practice: an overview of the issues. Ecological Economics 65: 663-674. - doi: 10.1016/j.ecolecon.2008.03.011

European Union (2003). Nature 2000: challenges and opportunities. Interpretation Guide. Office for Official Publications of the European Communities, Luxembourg, Belgium.

Hellström E (2001). Conflict cultures - Qualitative comparative analysis of environmental conflicts in forestry. Silva Fennica Monographs 2, The Finnish Forest Research Institute, The Finnish Society of Forest Science, pp. 109. [online] URL: http://www.metla.fi/silvafennica/full/smf/ smf002.pdf

Janse G, Ottitsch A (2005). Factors influencing the role of non-wood forest products and services. Forest Policy and Economics 7: 309-319. doi: 10.1016/S1389-9341(03)00068-6

Katoomba Group (2008). Ecosystem marketplace: the PES matrix. [online] URL: http://ecosystemmarketplace.com/documents/acrobat/PES_MATRIX_06-16-08_oritented.pdf

Lande-ll Mills N, Porras N (2002). Silver bullet or fool's gold? A global review of markets for forest environmental services and their impact on the poor. Instruments for sustainable private sector forestry series, International Institute for Environment and Development, London, UK. [online] URL: http://www.iied.org/pubs/pdfs/ 9066IIED.pdf

Loreggian F (2008). I Parchi Avventura: un'opportunità per i gestori forestali. BSc Thesis, University of Padua, Department of Land and Agroforestry Systems.

Mantau U, Merlo M, Sekot W, Welcker B (2001). Recreational and environmental markets for forest enterprises - a new approach towards marketability of public goods. CABI Publishing, Wallingford, UK.

Marshall E, Rashton J, Schreckenberg E, Arancibia E, Edouard F, Newton A (2006). Practical tools for researching successful NTFP commercialization: a methods manual. United Kingdom Department for International Development (DFID), Project R7925, Forestry Research Programme.

Merlo M, Briales ER (2000). Public goods and externalities linked to Mediterranean forests: economic nature and policy. Land Use Policy 17: 197-208. - doi: 10.1016/S0264-8377(00)00017-X Merlo M, Croitoru L (2005). Valuing Mediterranean forests. Towards total economic value. CABI Publishing, Wallingford, UK.

Merlo M, Milocco E, Panting R, Virgilietti P (2000). Transformation of environmental recreational goods and services provided by forestry into recreational environmental products. Forest Policy and Economics 1: 127-138. - doi: 10.1016/S1389-9341(00)00020-4

Muraro G (2008). Water services and water policy in Italy. In: "Development and environmental management: experiences and case studies" (Clini C, Musu I, Gullino ML eds). Springer, The Netherlands, pp. 65-80. - doi: 10.1007/978-14020-8229-0_5

Niemelä J, Young J, Alard D, Askasibar M, Henle K, Johnson R, Kurttila M, Larsson TB, Matouch S, Nowicki P, Paiva R, Portoghesi L, Smulders R, Stevenson A, Tartes U, Watt A (2005). Identifying, managing and monitoring conflicts between forest biodiversity conservation and other human interests in Europe. Forest Policy and Economics 7: 877-890. - doi: 10.1016/j.forpol. 2004.04.005

Pagiola S (2002). Paying for water services in 
Central America: Learning from Costa Rica. In: "Selling forest environmental services - marketbased mechanisms for conservation and development" (Pagiola S, Bishop J, Landell-Mills N eds). Earthscan, London, UK, pp. 37-61.

Pagiola S, Bishop J, Landell-Mills N (2002). Selling forest environmental services - Marketbased mechanisms for conservation and development. Earthscan, London, UK.

Palahí M, Mavsar R, Gracia C, Birot Y (2008). Mediterranean forests under focus. International Forestry Review 10 (4): 676-688. - doi 10.1505/ifor.10.4.676

Parrotta J, Agnoletti M, Johann E (2006). Cultural heritage and sustainable forest management: the role of traditional knowledge. In: "Proceedings of the IUFRO-MCPFE Conference", Florence (Italy) 8-11 June 2006. MCPFE Liaison Unit, Warszaw, PL.

Perrot-Maître D, Davis P (2001). Case studies of markets and innovative financial mechanisms for water services from forests. [online] URL: http:/ www.forest-trends.org/documents/publications/
casesWSofF.pdf

Pettenella D, Maso D, Secco L (2008). The netsystem model in NWFP marketing: the case of mushrooms (Italy). In: "Small-scale rural forest use and management: global policies versus local knowledge" (Buttoud G ed). Proceedings of the International Symposium held in Gérardmer 2327/07/2008 AgroParisTech, Conseil Général des Vosges, The University of Queensland, IUFRO, pp. 167-176.

Rametsteiner E (2000). The role of governments in SFM-certification. Discussion Paper $\mathrm{Nr}$. P/2000-1, Forest Sector Policy and Economics, University of Agricultural Sciences, Vienna, Austria.

Rametsteiner E, Weiss G, Kubezko K (2006). Innovation and entrepreneurship in forestry in Central Europe. EFI Research Report 19, European Forest Institute, Joensuu, Finland, pp. 180.

Secco L, Pettenella D (2006). Participatory processes in forest management: The Italian experience in defining and implementing forest certi- fication schemes. Schweizerische Zeitschrift für Forstwesen 157 (10): 445-452. - doi: 10.3188/ szf.2006.0445

Shannon MA (2006). Participation as social inquiry and social learning. Schweizerische Zeitschrift für Forstwesen 157 (10): 430-437. - doi: 10.3188/szf.2006.0430

Solberg B, Miina S (1997). Conflicts management and public participation in land management. EFI Proceedings, Joensuu, Finland, pp. 14-340.

Wunder S (2005). Payments for environmental services: some nuts and bolts. CIFOR Occasional Paper No. 42. [online] URL: http://www.cifor.cgiar.org/publications/pdf_files/OccPapers/OP42.pdf

Wunder S, Engel S, Pagiola S (2008). Taking stock: a comparative analysis of payments for environmental service programs in developed and developing countries. Ecological Economics 65 834-852. - doi: 10.1016/j.ecolecon.2008.03.010

Yin RK (1993). Applications of case study research. Applied social research methods series, Sage, Newbury Park, CA, USA, vol. 34. 